\title{
AKTA PERJANJIAN PENGIKATAN JUAL BELI RUMAH/ RUMAH SUSUN SEBAGAI PERLINDUNGAN HUKUM BAGI PENJUAL DAN PEMBELI
}

\author{
Safira Riza Rahmani, Nynda Fatmawati Octarina; Magister Kenotariatan Fakultas Hukum, \\ Universitas Narotama; Jl. Arif Rahman Hakim No. 51, Surabaya, Indonesia; \\ E-mail : yourrisa@gmail.com
}

\begin{abstract}
Abstrak
Tujuan dari penelitian hukum ini untuk mengetahui aspek perlindungan hukum dalam akta Perjanjian Pengikatan jual beli rumah/sarusun bedasarkan peraturan perundang-undangan yang berlaku dan memberikan sumbangsih kepada notaris dan masyarakat terutama dibidang hukum penataan ruang dan perumah/rusunan. Penelitian ini menggunakan metode penelitian hukum yuridis normatif dengan pendekatan perundang-undangan dan konseptual. Rumah/sarusun sebagai tempat berlindung sangat dibutuhkan oleh setiap orang, dengan tingginya harga rumah/sarusun yang diperjual belikan oleh pengusaha sehingga terdapat fakta hukum mengenai wanprestasi dalam hal jual beli rumah/sarusun pada saat proses pembangunan. Untuk menjamin kepastian hukum mengenai penjualan unit rumah/sarusun pada tahap pembangunan dibutuhkan alat bukti yang kuat berupa akta autentik yang bersumber pada aturan perundang-undangan yang mengatur mengenai perjanjian pengikatan jual beli antara developer dan pembeli untuk menghindari sengketa dikemudian hari. Disimpulkan bahwa pelaku pembangunan wajib membuat alat bukti autentik berupa akta autentik dihadapan pejabat umum/notaris dan mematuhi klausula dalam akta tersebut.
\end{abstract}

Kata Kunci: Akta perjanjian pengikatan jual beli, Rumah, Satuan rumah susun

\section{Abstract}

The purpose of this legal research to review about aspects of Preliminary Deed of Agreement on the sale and purchase of house/apartement based on the applicable laws and regulations and contribute to the notary public and citizen too. This research uses normative juridical legal research methods with statute approach and conceptual approach. The conclucion of this research the developer and buyer must make preliminary contract made by notary public

Keywords: PPJB , Housing law, notary public

\section{PENDAHULUAN \\ Latar Belakang}

Tanah merupakan elemen dari bumi yang dibutuhkan makhluk hidup untuk memperoleh bahan pangan dan manfaat lain bagi kehidupan umat manusia. Tanah tersebut dapat dikuasai atau dimiliki oleh setiap orang sesuai dengan hukum yang berlaku. ${ }^{1}$ Bertambahnya jumlah manusia yang tidak sebanding dengan luas lahan dibutuhkan peran serta dari negara untuk menciptakan ketertiban masyarakat di dalam masyarakat melalui aturan yang bersifat memaksa dalam bentuk tertulis, negara selaku otoritas yang menguasai dan memiliki tanah sebagaimana dalam Pasal 33 ayat (3) Undang-Undang Dasar Republik Indonesia Tahun 1945 (UUD NRI 1945) yang dirumuskan bahwa "Bumi, air, dan kekayaan alam yang terkandung didalamnya dikuasai oleh negara dan dipergunakan untuk sebesarbesarnya kemakmuran rakyat". Pasal ini melahirkan dasar-dasar pemikiran secara filosofi mengenai aturan di bidang agraria yang untuk menggantikan aturan dari Hindia Belanda dengan diundangkannya Undang-Undang Republik Indonesia Nomor 5 Tahun 1960 tentang

\footnotetext{
${ }^{1}$ Kartasapoetra, S, dkk, Hukum Tanah Jaminan UUPA Bagi Keberhasilan Pendayagunaan Tanah, Jakarta, Rineka Cipta, 1985, h. 5
} 
Undang-Undang Pokok Agraria (UUPA) dikarenakan peraturan era Hindia Belanda tidak mencerminkan hak asasi manusia dan bersifat mengandung unsur kapitalisme. Dengan pemikiran negarawan untuk mengubah aturan dibidang agrarian, maka undang-undang pokok agraria diundangkan sebagai dasar bagi penyusunan hukum agraria nasional yang diharapkan untuk kemakmuran, kebahagiaan dan keadilan bagi negara dan rakyat, serta menyederhanakan pengaturan mengenai hukum pertanahan, dan sebagai dasar untuk memberikan kepastian hukum mengenai hak atas tanah bagi rakyat.

UUPA membagi hak atas tanah dalam Pasal 16 yaitu hak milik, hak guna usaha, hak guna bangunan, hak pakai, hak sewa, hak membuka tanah hak memungut hasil hutan, hak lain, hak atas air dan ruang angkasa. Dalam rangka untuk memberikan kepastian hukum bagi hak atas tanah tersebut perlu dilakukan pendaftaran hak atas tanah sebagaimana dalam Pasal 19 UUPA. Atas bidang tanah dapat dibangun berbagai bangunan sesuai dengan peruntukan lahan tersebut. Undang-Undang Republik Indonesia Nomor 1 Tahun 2011 tentang Perumahan dan Kawasan Permukiman (UU Perumahan dan Kawasan Permukiman) mengatur mengenai rumah/rusun yang dapat dibangun diatas hak atas tanah. Apabila merujuk pada nomenklatur UU Perumahan dan Kawasan Permukiman terdapat dua kata kunci yaitu Perumahan dan Kawasan Permukiman. Unsur-unsur perumahan menurut Pasal 1 ayat 1 UU Perumahan dan Kawasan Permukiman adalah:

a. kumpulan rumah/rusun sebagai bagian dari permukiman baik perkotaan maupun perdesaan,

b. dilengkapi dengan prasarana, sarana, dan utilitas umum sebagai hasil upaya pemenuhan rumah/rusun yang layak huni.

Sedangkan unsur kawasan permukiman menurut UU Perumahan dan Kawasan Permukiman diantaranya sebagai berikut:

a. bagian dari lingkungan hidup di luar kawasan lindung baik berupa kawasan perkotaan maupun perdesaan

b. sebagai lingkungan tempat tinggal/lingkungan hunian dan tempat kegiatan yang mendukung perikehidupan dan penghidupan.

Setiap pemegang hak atas tanah dapat memanfaatkan serta mengalihkan hak atas tanah sesuai dengan kebutuhan pemegang hak atas tanah tersebut. Terhadap rumah/satuan rumah susun yang dibangun diatas hak atas tanah dapat beralih atau dialihkan, terdapat bentuk peralihan rumah/satuan rusun diatas hak atas tanah yaitu:

1. Beralih

adalah berpindahnya hak atas tanah dari pemegang hak sebelumnya kepada pihak lain karena suatu peristiwa hukum, seperti misalnya pewarisan dari pewaris kepada ahli waris.

2. Dialihkan

adalah berpindahnya hak atas tanah dari pemegang hak atas tanah kepada pihak lain karena suatu perbuatan hukum, seperti jual beli, tukar menukar, wakaf, hibah, lelang, dan pemasukan dalam modal perusahaan. ${ }^{2}$

2 Santoso, Urip, Pendaftaran dan Peralihan Hak Atas Tanah, Jakarta, Kencana, 2010, h. 399. 
Mengacu pada uraian diatas peralihan rumah/satuan unit rusun melalui proses jual beli dapat dilakukan oleh perorangan atau dengan badan hukum yang memiliki bisnis dibidangnya. Menurut Pasal 1457 BW “Jual beli adalah suatu persetujuan dengan mana pihak yang satu mengikatkan dirinya untuk menyerahkan suatu barang, dan pihak yang lain untuk membayar harga yang dijanjikan". UUPA mengadopsi hukum adat, yangmana proses jual beli dilakukan secara tunai dan terang dihadapan PPAT sebagai pejabat yang membantu menteri ATR/BPN dalam hal melakukan proses pendaftaran hak atas tanah atau PPAT Sementara, maksud tunai ialah pembeli membeli unit rumah/rusun tersebut secara kontan atau lunas.

Pembeli rumah/satuan rusun terkadang tidak dapat melunasi harga jual rumah/rusun dikarenakan kondisi tertentu sehingga pembeli hanya dapat membayar Down Payment (DP/uang muka) pada saat pembangunan unit. Kondisi lain yang menyebabkan belum terpenuhinya syarat ditandatanganinya akta jual beli seperti pembeli dan penjual belum membayar pajak, atau sedang dalam proses pemecahan sertifikat atas unit rumah/rusun tersebut. Atas sebab tidak dapat dilaksanakan penandatanganan akta jual beli, para pihak dapat membuat perjanjian pengikatan sebagai perjanjian pendahuluan jual beli rumah/rusun. Sistem pendahuluan jual beli diatur dalam Pasal 42 UU Perumahan dan Kawasan Permukiman, yang kemudian diatur lebih lanjut dalam PERMENPUPR No. 11/PRT/M/2019 tentang Sistem Perjanjian Pendahuluan Jual Beli Rumah/Rusun sebagai petunjuk kepada notaris dan masyarakat dalam melaksanakan pembuatan akta PPJB rumah/rusun.

Peraturan Menteri PUPR tersebut mencabut SK Menteri Perumahan Rakyat Nomor 11/KPTS/1994 tentang Pedoman Perikatan Jual Beli Satuan Rumah SK Menteri Rakyat Nomor 09/KPTS/M/1995 tentang Pedoman Pengikatan Jual Beli Rumah/rusun. Politik hukum pembentukan peraturan tersebut untuk memenuhi kebutuhan di bidang legislasi mengenai perjanjian pengikatan jual beli rumah/rusun atau rusun bagi pelaku usaha atau masyarakat, serta tuntutan akan kepastian hukum mengenai pelaku usaha/ pembangunan mengenai pembangunan unit rumah/rusun/rusun sesuai dengan yang diperjanjikan dan menghindari tindak pidana penipuan atau penyalahgunaan baik pelaku usaha atau pembeli rumah/sarusun. ketentuan dalam PERMENPUPR ini yang mewajibkan akta PPJB dibuat dihadapan notaris sebagai bukti yang kuat yang mengikat para pihak dalam menjalankan klausul yang diperjanjikan. Selanjutnya akan dibahas lebih lanjut mengenai karakteristik akta perjanjian pendahuluan jual beli rumah/sarusun dan akibat hukum tidak dilaksanakannya klausul dalam akta perjanjian pendahuluan jual beli rumah/sarusun.

\section{Rumusan Masalah}

1. Karakteristik akta perjanjian pendahuluan jual beli rumah/sarusun

2. Akibat hukum tidak dilaksanakannya klausul dalam akta perjanjian pendahuluan jual beli rumah/sarusun 


\section{METODE PENELITIAN}

Penelitian ini menggunakan metode penelitian hukum normatif. Penelitian hukum normatif atau dapat disebut penelitian hukum yuridis normatif adalah metode penelitian hukum yang dilakukan dengan cara peneliti melakukan penelitian bahan pustaka yang digunakan sebagai referensi penelitian. ${ }^{3}$ Penelitian hukum ini menggunakan metode pendekatan yaitu4:

1. Pendekatan perundang-undangan

pendekatan perundang-undangan suatu pendekatan yang dilakukan terhadap berbagai aturan hukum yang berkaitan dengan peraturan perundang-undangan yang beralku dan berkaitan dengan isu hukum mengenai pembuatan akta PPJB rumah/sarusun.

2. Pendekatan konseptual

Pendekatan konsep digunakan untuk memahami konsep-konsep tentang landasan filosofis yang menjadi urgensi pengaturan mengenai akta PPJB rumah/sarusun.

\section{PEMBAHASAN}

\section{Karakteristik Akta Perjanjian Pendahuluan Jual Beli Rumah/Sarusun}

Manusia dalam memenuhi kebutuhannya membutuhkan bantuan manusia lain, bantuan tersebut menyebabkan keterikatnya antar pihak. Perikatan adalah suatu hubungan hukum antara dua orang atau dua pihak lain, sehingga timbul akibat hukum dengan mana pihak yang satu berhak menuntut pihak yang lain, dan pihak yang lain berkewajiban untuk memenuhi tuntutan itu. ${ }^{5}$ Suatu perikatan dapat bersumber dari undang-undang atau perjanjian, Perikatan yang lahir dari undang-undang diatur dan ditetapkan bedasarkan undang-undang di luar keinginan dari pihak yang bersangkutan. Perjanjian didefinisikan dalam Pasal 1313 BW yang rumusan nya disebutkan bahwa "suatu perjanjian adalah suatu perbuatan dengan mana satu orang, atau lebih mengikatkan dirinya terhadap satu orang atau lebih".

Aturan dalam Buku III BW menganut sistem terbuka, maksud dari sistem terbuka dalam buku III BW yakni pembentuk undang-undang memberikan kebebasan/keleluasaan kepada setiap orang untuk membuat perjanjian yang sesuai dengan aturan dan tidak melanggar ketertiban umum dan kesusilaan. Perjanjian melahirkan akibat hukum dari para pihak untuk melaksanakan hak dan kewajiban dalam perjanjian tersebut. Mengenai daya ikat perjanjian diatur dalam Pasal 1338 BW yang dirumuskan bahwa "Semua persetujuan yang dibuat sesuai dengan undang-undang berlaku sebagai undang-undang bagi mereka yang membuatnya", aturan ini menganut asas hukum pacta sunt servanda. Agar perjanjian jual beli sah menurut peraturan perundang-undangan maka perjanjian wajib memenuhi unsur Pasal 1320 BW yaitu:

\footnotetext{
${ }^{3}$ Soekanto, Soerjono, dkk, Penelitian Hukum Normatif (Suatu Tinjauan Singkat), Jakarta, Rajawali pers, 2001, h. 13-14.

${ }^{4}$ Ibrahim, Johny, Teori, Metode dan Penelitian Hukum Normatif, Cet.4, Malang, Bayumedia Publishing, 2011, h. 30 .

5 Subekti, Hukum Perjanjian, Jakarta, Intermasa, 1990, h. 1.
} 
1. Sepakat

Maksud dari kata sepakat ialah para pihak bersedia untuk mengikatkan dirinya dalam perjanjian jual beli dan menjadikan pedoman bagi para pihak layaknya undang-undang

2. Cakap untuk melakukan perbuatan hukum

Yang dimaksud dengan Cakap ialah bahwa seseorang tersebut mampu secara fisik rohani untuk melakukan klausula klausula yang diperjanjikan dalam perjanjian tersebut, BW mengatur kondisi seseorang yang tak cakap untuk membuat perjanjian adalah:

- anak yang belum dewasa;

Ketentuan mengenai usia anak yang belum dewasa diantaranya:

- Pasal 47 UU No 1 Tahun 1974 Tentang Perkawinan

(1) Anak yang belum mencapai umur 18 (delapan belas) tahun atau belum pernah melangsungkan perkawinan ada dibawah kekuasaan orang tuanya selama mereka tidak dicabut dari kekuasaannya.

(2) Orang tua mewakili anak tersebut mengenai segala perbuatan hukum didalam dan diluar Pengadilan.

- Pasal 1 angka 26 UU 13 Tahun 2003 tentang Perlindungan Anak:

Anak adalah setiap orang yang berumur dibawah 18 (delapan belas) tahun.

- Kondisi kedua bahwa orang yang tak cakap hukum merupakan orang yang ditaruh di bawah pengampuan sebagaimana yang diatur dalam Pasal 433 BW dinyatakan bahwa:

"Setiap orang dewasa, yang selalu berada dalam keadaan dungu, gila atau mata gelap, harus ditempatkan di bawah engampuan, sekalipun ia kadang-kadang cakap menggunakan pikirannya. Seorang dewasa boleh juga ditempatkan di bawah pengampuan karena keborosan".

- Kondisi ketiga bahwa seorang perempuan yang telah kawin dalam hal-hal yang ditentukan undang-undang, dan pada umumnya semua orang yang oleh undangundang dilarang untuk membuat perjanjian tertentu. Ketentuan ini tak lagi digunakan, sebab kesetaraan gender antara pria dan wanita adalah sejajar, dalam ketentuan Pasal 31 ayat 1 dan ke 2 Undang-Undang Republik Indonesia Nomor 1 Tahun 1974 tentang Perkawinan disebutkan bahwa:

(1) Hak dan kedudukan isteri adalah seimbang dengan hak dan kedudukan suami dalam kehidupan rumah/rusun tangga dan pergaulan hidup bersama dalam masyarakat;

(2) Masing-masing pihak berhak untuk melakukan perbuatan hukum

3. Suatu hal tertentu

Pasal ini berkaitan dengan objek perjanjian, bahwa obyek yang dapat diperjanjikan merupakan objek yang bernilai ekonomi dan barang tersebut harus diterangkan secara jelas dalam klausul perjanjian

4. Sebab yang diperbolehkan

Obyek yang diperjanjikan dalam klausul perjanjian merupakan obyek yang dapat diperjual belikan menurut undang-undang.

Dilihat dari jenis perjanjian, buku III BW memberikan aturan mengenai Perjanjian bernama dan tidak bernama, perjanjian bernama merupakan perjanjian yang diatur dalam 
BW sedangkan perjanjian tidak bernama diatur dalam peraturan perundang-undangan diluar BW. Salah satu perjanjian bernama dalam BW ialah perjanjian jual beli diatur dalam Pasal 1457 BW - 1540 BW. Definisi jual beli menurut Pasal 1457 BW ialah "suatu persetujuan dengan mana pihak yang satu mengikatkan dirinya untuk menyerahkan suatu barang dan pihak yang lain untuk membayar harga yang dijanjikan". Jual beli dilakukan oleh pihak penjual dan pembeli dengan akibat hukum para pihak berkewajiban dan memiliki hak dalam perjanjian itu. ${ }^{6}$

Merujuk pada syarat ketiga dan keempat dalam Pasal 1320 BW, bahwa suatu perjanjian wajib memiliki obyek yang diperjanjikan. obyek jual beli dapat berupa bangunan dan/ atau lahan yang akan dijadikan sebagai tempat tinggal berupa rumah/sarusun. Jual beli secara hukum adat dilaksanakan secara tunai dan terang dihadapan PPAT/PPATS, namun kondisi tertentu dan dibutuhkannya modal yang tidak sedikit maka pelaku usaha di bidang perumah/rusunan dan pembeli dapat membuat perjanjian pendahuluan sebelum ditandatanganinya akta jual beli. Bedasarkan Pasal 42 ayat 3 UU Perumahan dan Kawasan Permukiman dan Peraturan Menteri Pekerjaan Umum dan Perumahan rakyat No. 11/PRT/M/2019 Tentang Sistem Perjanjian Pendahuluan Jual Beli Rumah (selanjutnya disebut PERMENPUPR Sistem Perjanjian Pendahuluan Jual Beli Rumah) diatur mengenai hal-hal yang harus di atur dalam PPJB. Dengan diundangkannya peraturan ini sehingga peraturan ini mencabut beberapa peraturan yakni Keputusan Menteri Perumahan Rakyat No. 11/KPTS/1994 tentang Pedoman Perikatan Jual Beli Satuan Rumah/rusun Susun dan Keputusan Menteri Negara Perumahan Rakyat Nomor 09/KPTS/M/1995 tentang Pedoman Pengikatan Jual Beli Rumah yang dicabut dan dinyatakan tidak berlaku.

Urgensi Menteri PUPR mengatur sistem PPJB Rumah/rusun dikarenakan atas laporan dari masyarakat mengenai pelaku usaha yang tidak melaksanakan isi perjanjian akta PPJB dan menyebabkan kerugian bagi masyarakat. Peraturan Menteri PUPR tersebut mengatur mengenai kegiatan pemasaran rumah/rusun sampai dengan ditandatanganinya akta PPJB, dengan adanya peraturan ini maka pelaku usaha dan pembeli akan mendapat kepastian hukum mengenai PPJB rumah/rusun beserta hak dan kewajibannya. Perjanjian dapat dibuat dibawah tangan atau dengan akta notaris, dalam hal ini PPJB diwajibkan untuk dibuat dihadapan notaris Bedasarkan Pasal 12 ayat 2 PERMENPUPR Sistem Perjanjian Pendahuluan Jual Beli Rumah/rusun yang disebutkan bahwa notaris berwenang untuk membuat akta pengikatan jual beli rumah/rusun.

Perjanjian PPJB yang dibuat secara notariil memiliki beberapa fungsi diantaranya yakni:

a. Sebagai bukti bahwa para pihak yang bersangkutan telah mengadakan perjanjian tertentu.

b. Sebagai bukti bagi para pihak bahwa apa yang tertulis dalam perjanjian adalah menjadi tujuan dan keinginan para pihak.

c. Sebagai bukti kepada pihak ketiga bahwa pada tanggal tertentu, kecuali jika ditentukan sebaliknya para pihak telah mengadakan perjanjian dan bahwa isi perjanjian adalah

${ }^{6}$ Kansil,C.S.T, Hukum Perdata I (Termasuk Asas - Asas Hukum Perdata), Jakarta, Pradnya Paramita, 1991, h. 238 . 
sesuai dengan kehendak para pihak. ${ }^{7}$

Dalam pembuatan akta perjanjian pengikatan jual beli melalui beberapa tahap, yang pertama merupakan administrasi awal yakni pelaku pembangunan melampirkan beberapa dokumen untuk dipelajari notaris antara lain:

a. Sertifikat hak atas tanah dan fotokopinya (notaris wajib mengecek ke kantor pertanahan mengenai blokir atau sengketa atas lahan tersebut)

b. Ditetapkan ijin lokasi dan SKRK pelaku usaha

c. BAST administrasi fasum fasos antara pengembang dan pemerintah daerah

d. IMB

e. Pernyataan dari pelaku pembangunan mengenai telah terbangunnya lokasi perumah/rusunan tunggal atau rumah/rusun deret paling sedikit $20 \%$ dari jumlah unit rumah/rusun serta dengan dilengkapi ketersediaan fasilitas saluran air, drainase, sumber listrik dan air (dibuktikan dengan hasil laporan dari konsultan pengawas pembangunan atau konsultan manajemen konstruksi)

f. Surat pernyataan keterbangunan rumah/rusun susun paling sedikit $20 \%$ dari volume konstruksi bangunan rumah/rusun susun yang sedang dipasarkan (dibuktikan dengan hasil laporan dari konsultan pengawas pembangunan atau konsultan manajemen konstruksi)

g. Dokumen penghadap seperti fotokopi legalisir akta pendirian dan perubahan perseroan terbatas pelaku usaha, fotokopi KTP direktur dan calon pembeli, NPWP, SPPT PBB dan bukti bayar tahun terakhir, buku nikah calon pembeli, kartu keluarga, dan dokumen lain yang diperlukan serta dokumen pendukung dari pembeli rumah/rusun seperti fotokopi buku nikah, kartu keluarga, kartu tanda penduduk, dan sebagainya.

Suatu akta notaris wajib mengikuti standar yang telah ditetapkan oleh aturan hukum yang berlaku sebagaimana dalam Pasal 1868 BW, pengaturan mengenai notaris diatur dalam Undang-Undang Republik Indonesia Nomor 2 Tahun 2014 tentang Perubahan Atas Undang-Undang Nomor 30 Tahun 2004 tentang Jabatan Notaris.

Dalam membuat akta notaris wajib memperhatikan format bentuk akta notaris diatur dalam Pasal 38 Undang-Undang Jabatan Notaris dan Perubahannya yakni:

(1) Setiap Akta terdiri atas:

a. awal Akta atau kepala Akta;

b. badan Akta;

c. akhir atau penutup Akta.

(2) Awal Akta atau kepala Akta memuat:

a. judul Akta;

b. nomor Akta;

c. jam, hari, tanggal, bulan, dan tahun; dan

d. nama lengkap dan tempat kedudukan Notaris.

(3) Badan Akta memuat:

a. nama lengkap,

7 H.S, Salim, Hukum Kontrak Teori dan Teknik Penyusunan Kontrak, Jakarta, Sinar Grafika, 2010, h.43 
b. tempat dan tanggal lahir,

c. kewarganegaraan,

d. pekerjaan,

e. jabatan,

f. kedudukan,

g. tempat tinggal para penghadap dan/atau orang yang mereka wakili;

h. keterangan mengenai kedudukan bertindak penghadap

Isi Akta yang merupakan kehendak dan keinginan dari pihak yang berkepentingan; dan nama lengkap, tempat dan tanggal lahir, serta pekerjaan, jabatan, kedudukan, dan tempat tinggal dari tiap-tiap saksi pengenal.

(4) Akhir atau penutup Akta memuat:

Uraian tentang pembacaan Akta sebagaimana dimaksud dalam Pasal 16 ayat (1) huruf $m$ atau Pasal 16 ayat (7);

a. uraian tentang penandatanganan dan tempat penandatanganan atau penerjemahan Akta jika ada;

b. nama lengkap, tempat dan tanggal lahir, pekerjaan, jabatan, kedudukan, dan tempat tinggal dari tiap-tiap saksi Akta; dan

c. uraian tentang tidak adanya perubahan yang terjadi dalam pembuatan Akta atau uraian tentang adanya perubahan yang dapat berupa penambahan, pencoretan, atau penggantian serta jumlah perubahannya.

Suatu akta mempunyai karakteristik yang dapat dilihat dari susunan setiap pasal demi pasal saling berkaitan, termasuk pula pada akta PPJB rumah/sarusun yang diatur dalam lampiran PERMENPUPR Sistem Perjanjian Pendahuluan Jual Beli Rumah tentang petunjuk materi muatan akta PPJB rumah/rusun yang diantaranya memuat:

1. Kepala akta

Memuat judul, nomor, jam, hari, tanggal, bulan, tahun, nama lengkap, dan tempat kedudukan notaris.

2. Identitas para pihak

Memuat nama lengkap, tempat tanggal lahir, kewarganegaraan, pekerjaan, jabatan, kedudukan, tempat tinggal para pihak.

3. Uraian objek PPJB dengan menjelaskan

Data fisik yang menjelaskan luas tanah dan luas bangunan untuk rumah tunggal dan rumah deret, atau luas sarusun, letak objek dan lokasi.

4. Harga rumah/sarusun dan tata cara pembayaran diantaranya Harga penjualan, tata cara, waktu, biaya yang timbul dari perjanjian, larangan pelaku pembangunan untuk menarik dana lebih dari $80 \%$ sebelum memnuhi persyaratan.

5. Jaminan dari pelaku pembangunan mengenai kepemilikan, keabsahan, bebas dari sengketa dan jaminan bukti kepemilikan.

6. Hak dan kewajiban para pihak

7. Waktu serah terima bangunan

8. Pemeliharaan bangunan

9. Pengguna bangunan 
10.Pengalihan hak

11.Pembatalan dan berakhirnya PPJB

12. Penyelesaian sengketa

13.Penutup

14.Lampiran terdiri atas

a. Untuk rumah tunggal atau rumah deret melampirkan gambar bangunan yang dipotong secara vertical dan memperlihatkan isi atau bagian dalam bangunan dan denah yang menunjukkan lokasi rumah.

b. Untuk rumah susun dengan satu bangunan rumah susun melampirkan gambar denah tanah bersama, gambar ruangan yang dipotong vertical, denah yang menunjukkan sarusun berada.

c. Untuk rumah susun dengan lebih dari satu bangunan dilampirkan gambar lokasi satu bangunan rumah susun atau blok, gambar atau batas tanah bersama, gambar bangunan yang dipotong vertical dan memperlihatkan isi bangunan dan lantai sarusun berada.

\section{Akibat Hukum Tidak Dilaksanakannya Klausul Dalam Akta Perjanjian} Pendahuluan Jual Beli Rumah/Sarusun

Perjanjian merupakan sumber perikatan yang diatur dalam buku III BW, asas asas hukum diterapkan dalam buku III BW sebagai Perjanjian dibuat bedasarkan asas-asas hukum diantaranya:

a. Asas perjanjian/kontrak sebagai hukum mengatur, merupakan peraturanperaturan hukum yang berlaku bagi subjek hukum. Dalam hal ini para pihak dalam suatu kontrak.

b. Asas kebebasan berkontrak, hal ini merupakan konsekuensi dari berlakunya asas kontrak sebagai hukum mengatur. Dalam suatu kontrak para pihak pada prinsipnya bebas untuk membuat atau tidak membuat kontrak, demikian juga kebebasannya untuk mengatur sendiri isi kontrak tersebut.

c. Asas Fakta Sunt Servanda, adalah janji itu mengikat, bahwa suatu kontrak dibuat secara sah oleh para pihak mengikat para pihak tersebut secara penuh sesuai isi kontrak tersebut.

d. Asas konsensual, bahwa jika suatu kontrak sudah dibuat, maka dia telah sah dan mengikat secara penuh, bahkan pada prinsipnya persyaratan tertulispun tidak disyaratkan oleh hukum, kecuali untuk beberapa jenis kontrak tertentu, yang memang dipersyaratkan untuk tertulis.

e. Asas obligatoir, yaitu jika suatu kontrak sudah dibuat, maka para pihak telah terikat, tetapi keterikatannya itu hanya sebatas timbulnya hak dan kewajiban semata-mata ${ }^{8}$

Perjanjian menyebabkan keterikatan para pihak yang wajib dipenuhi, namun terdapat beberapa sebab yang menyebabkan tidak dapat dipenuhinya prestasi atau

8Fuady, Munir, Pengantar Hukum Bisnis, Bandung, Citra Aditya Bakti, 2002, h.13. 
dapat disebut wanprestasi, definisi Wanprestasi adalah tidak dapat memenuhi atau melaksanakan kewajiban sebagaimana yang ditentukan dalam perjanjian yang dibuat antara para pihak. ${ }^{9}$ Beberapa tindakan yang dapat dikatakan sebagai tindakan wanprestasi itu dapat berupa:

1. Tidak memenuhi kewajiban sama sekali

2. Terlambat melaksanakan kewajiban/presatsi.

3. Memenuhi prestasi tetapi tidak sesuai atau keliru yang diperjanjikan.10

Berkaitan dengan perjanjian PPJB, PERMENPUPR Sistem Perjanjian Pendahuluan Jual Beli Rumah/rusun mengatur beberapa penyebab tidak dapat dipenuhinya prestasi dalam PPJB sebagaimana dalam Pasal 9 yaitu:

1. Apabila pelaku usaha lalai memenuhi jadwal sebagaimana dalam Pasal 7 ayat 2 maka calon pembeli dapat membatalkan pembelian rumah/rusun, maka pembayaran tersebut wajib untuk dikembalikan sepenuhnya kepada calon pembeli

2. Apabila calon pembeli membatalkan bukan disebabkan kelalaian pelaku usaha maka pelaku usaha mengembalikan pembayaran dengan dapat memotong $10 \%$ dari pembayaran yang telah diterima ditambah biaya pajak yang telah diperhitungkan (ayat 3)

Atas wanprestasi yang dilakukan oleh pihak pembeli atau penjual, maka aka nada akibat hukum yang ditanggung pihak yang wanprestasi. Pasal 13 PERMENPUPR Sistem Perjanjian Pendahuluan Jual Beli Rumah/rusun, mengatur akibat hukum atas tindakan wanprestasi dengan ringkasan sebagai berikut:

1. Apabila pembatalan PPJB dilakukan oleh pelaku pembangunan karena lalai maka seluruh pembayaran yang telah diterima harus dikembalikan kepada pembeli (ayat 1)

2. Apabila pembeli lalai memenuhi isi akta PPJB maka pelaku pembangunan dapat menerima hak pembayaran dengan ketentuan sebagai berikut:

a. Jika pembayaran telah dilakukan pembeli paling tinggi 10\% (sepuluh persen) dari harga transaksi keseluruhan pembayaran menjadi hak pelaku pembangunan; atau

b. Jika pembayaran telah dilakukan pembeli lebih dari $10 \%$ (sepuluh persen) dari harga transaksi, pelaku pembangunan berhak memotong 10\% (sepuluh persen) dari harga transaksi.

${ }^{9}$ HS, Salim, Pengantar Hukum Perdata Tertulis (BW), Jakarta, 2008, h.180.

${ }^{10}$ Meliala, A. Qirom Syamsuddin, Pokok-Pokok Hukum Perjanjian, Yogyakarta, Liberty, 1985, h.26 


\section{PENUTUP}

\section{Kesimpulan}

1. Pembuatan PPJB Rumah/Sarusun yang dibuat oleh notaris bedasarkan PERMENPUPR Sistem Perjanjian Pendahuluan Jual Beli Rumah/Sarusun mencerminkan asas kepastian hukum dengan tujuan melindungi hak pembeli maupun pelaku pembangunan rumah/sarusun serta berfungsi sebagai alat bukti yang kuat jika terjadi sengketa di kemudian hari.

2. Notaris wajib membuat akta PPJB sesuai dengan yang telah ditentukan dalam PERMENPUPR Sistem Perjanjian Pendahuluan Jual Beli Rumah/sarusun, dengan tetap merujuk pada Pasal 38 UU Jabatan Notaris dan Perubahannya.

\section{Saran}

Tidak semua notaris, masyarakat, pelaku usaha mengetahui diundangkannya peraturan PERMENPUPR Sistem Perjanjian Pendahuluan Jual Beli Rumah/Sarusun, sebaiknya dilakukan sosialisasi lebih lanjut mengenai PERMENPUPR Sistem Perjanjian Pendahuluan Jual Beli Rumah/Sarusun.

\section{DAFTAR PUSTAKA}

Fuady, Munir, Pengantar Hukum Bisnis, Bandung: Citra Aditya Bakti, 2002.

H.S, Salim, Hukum Kontrak Teori dan Teknik Penyusunan Kontrak, Jakarta: Sinar Grafika, 2010.

, Pengantar Hukum Perdata Tertulis (BW), Jakarta: Sinar Grafika, 2008.

Ibrahim, Johny, Teori, Metode dan Penelitian Hukum Normatif, Cet.4, Malang: Bayumedia Publishing, 2011.

Kansil, C.S.T, Hukum Perdata I (Termasuk Asas-Asas Hukum Perdata), Jakarta: Pradnya Paramita, 1991.

Kartasapoetra, S, dkk, Hukum Tanah Jaminan UUPA Bagi Keberhasilan Pendayagunaan Tanah, Jakarta: Rineka Cipta, 1985.

Meliala, A. Qirom Syamsuddin, Pokok-pokok Hukum Perjanjian, Yogyakarta: Liberty, 1985. Santoso, Urip, Pendaftaran dan Peralihan Hak Atas Tanah, Kencana: Jakarta, 2010.

Soekanto, Soerjono, dkk, Penelitian Hukum Normatif (Suatu Tinjauan Singkat), Jakarta: Rajawali Pers, 2001.

Subekti, Hukum Perjanjian, Jakarta: Intermasa, 1990. 